\title{
Model and method of conditional formula determination of oxygen-containing hydrocarbon fuel in combustion
}

\section{Olexander Brunetkin ${ }^{1}$,}

Yevhenii Dobrynin²,

Andrii Maksymenko ${ }^{1}$,

Oksana Maksymova ${ }^{3}$,

Svitlana Alyokhina ${ }^{4,5}$

${ }^{1}$ Odessa National Polytechnic University,

1 Shevchenko Ave.,

65044 Odesa, Ukraine

${ }^{2}$ Odessa State Academy

of Technical Regulation and Quality,

15 Kovalska St.,

65020 Odesa, Ukraine

${ }^{3}$ Odessa National Academy

of Food Technologies,

112 Kanatna St.,

65039 Odesa, Ukraine

${ }^{4}$ A. Podgorny Institute

of Mechanical Engineering Problems

of the National Academy of Sciences of Ukraine,

2/10 Pozharsky St.,

61046 Kharkiv, Ukraine

${ }^{5}$ V. N. Karazin Kharkiv National University,

4 Svobody Sq.,

61002 Kharkiv, Ukraine

Email:alyokhina@karazin.ua
In the paper, the cause that makes it difficult to use uncertified fuels has been identified - the uncertainty and variability of their composition. The mathematical model and the method that allow one to determine such a fuel composition in the combustion process are developed. Optimal parameters of the combustion process are proposed. The limitations imposed by the model on the method used are determined.

Keywords: oxygen-containing hydrocarbon fuel, fuel combustion, combustion products, modelling analysis, computation method 


\section{INTRODUCTION}

World trends in the price rising of natural energy sources and trends in the development of the industry of uncertified types of oxygen-containing hydrocarbon fuels cause interest in the solving of the problem of model and method creation that ensure an efficient combustion of such gases, the calorific value of which varies randomly in time. Moreover, the solution of such problem is also relevant for the ensuring of an efficient combustion of fuel with a variable calorific value, obtained in various technologies. These include gases in oil production, such as shale and mine gas, pyrolysis products, fermentation of organic residues, biofuels, blast-furnace gases, gases obtained by fermentation of garbage, etc. Particular attention should be paid to the ecological aspect of combustion: because of poor quality and incomplete combustion of such fuels, a large number of harmful organic compounds are formed and discharged into the surrounding environment.

\section{PROBLEM FORMULATION}

When using certified natural energy carriers as a fuel for power plants, the most important indicator is the constancy of their composition and, as a consequence, the constant calorific value, which allows one to ensure an efficient fuel combustion while minimizing harmful emissions in order to comply with environmental standards by adjusting the regime of power plants. In [1] the analysis of the atmospheric distribution of polycyclic aromatic hydrocarbons (PAH) for several years from various industrial sources in the study of urban and suburban facilities is presented. In the study it was shown that PAHs in aerosol particles at high concentrations were obtained during winter periods when fossil fuels were burned for space heating of residential premises. In non-heating seasons, the prevalence over the norm is obtained due to the exhaust gases of diesel and gasoline engines of cars. The particular interest is the study [2] on the spread of pollution in the atmosphere where volatile organic compound (VOC) concentrations have been measured and the sources of their origin have been identified. It should be noted that vehicles contribute $25 \%$ of the measured VOC concentration; industrial solvents up to $17 \%$; evap- orated fuel up to $15 \%$; solvents of dyes up to $15 \%$; industrial steel production $12 \%$; biomass and biofuel $9 \%$, and coal combustion up to $7 \%$. The resulted research materials $[1,2]$ have shown that for large industrial mega cities, the main task in the ecology perspective is to ensure the qualitative combustion of any type of hydrocarbon fuel, including for energy technologies of burning fuels in engines of transport installations.

\section{PURPOSE AND OBJECTIVES OF THE STUDY}

Determination of the gas composition with an unknown calorific value with usage of a gas analyser could be done. This method, however, has a number of drawbacks: it is resource-intensive, cumbersome, has a long inertia and, as a consequence, a lag. For gas analysers, data containing the list of gases in the mixture is required. The usage of gas analysers is complicated by the fact that such gases contain unwanted components, which lead to accelerated wear of primary devices and their failure. Therefore, such method is difficult to integrate into an automated control system.

The purpose of this article is to present the developed mathematical model for determining the composition of a mixture of hydrocarbon oxygen-containing gases in the model representation by its conditional formula with the initial data in the form of measured process parameters: the temperature of combustion products and the volume flow rates of the mixture and air.

To achieve this goal, it is necessary to solve a number of problems and develop a general mathematical model for solving the set goal, and to develop additional closing relations to find the solution in an analytical form if necessary. With this purpose, the authors consider the features of the model and use the example of a typical oxygen-containing hydrocarbon fuel to perform calculations.

\section{MATHEMATICAL MODEL FOR DETERMINING THE COMPOSITION OF COMBUSTION PRODUCTS}

Despite a variety of combustible substances, the process of formation of combustion products and the determination of their temperature can 
be described using a single model. The next will be considered: the model of the combustion process using the example of ethyl alcohol, which includes atoms of carbon, hydrogen and oxygen (C, $\mathrm{H}, \mathrm{O}$ ) in its composition. It is a representative of oxygen-containing hydrocarbons, covering a wide class of organic fuels. So the additional account of only two elements - sulphur and nitrogen $(\mathrm{S}, \mathrm{N})$ occurring in fuel in smaller quantities makes it possible to simulate almost all organic compounds burning in the air atmosphere [3-9]. With taking into account the chemical structure of ethyl alcohol, and considering that it is not necessary to take into account the structure of the substance in question, the conditional formula of fuel has the form

$$
\mathrm{C}_{\mathrm{b}_{\mathrm{C}}} \mathrm{H}_{\mathrm{b}_{\mathrm{H}}} \mathrm{O}_{\mathrm{b}_{\mathrm{O}}}
$$

for ethyl alcohol

$$
\mathrm{b}_{\mathrm{C}}=2, \mathrm{~b}_{\mathrm{H}}=6, \mathrm{~b}_{\mathrm{O}}=1 \text {. }
$$

The air was considered as an oxidizer. Its composition in volume fractions corresponds approximately to $21 \%$ of oxygen $\left(\mathrm{O}_{2}\right), 78 \%$ of nitrogen $\left(\mathrm{N}_{2}\right)$ and $1 \%$ of various impurities in the form of argon, carbon dioxide and other impurities that are generally inert. All impurities do not participate in the combustion process as well as nitrogen. Considering this, in order to simplify the calculations, all the impurities can be represented in the form of another $1 \%$ of $\mathrm{N}_{2}$. Ultimately, the air in the calculations is based on the composition: $21 \%$ of $\mathrm{O}_{2}, 79 \%$ of $\mathrm{N}_{2}$. The conditional formula is based on the number of atoms entering, for example, in the structural formula. Therefore, instead bulk mass fractions could be used. The next atomic masses are used:

$$
\mu_{\mathrm{O}}=15.9994 ; \mu_{\mathrm{N}}=14.0070 \text {. }
$$

In this case, taking into account the accepted percentage composition, the air formula will look like

$$
\mathrm{O}_{0.419} \mathrm{~N}_{1.581} \text {. }
$$

Consider the reaction of burning alcohol in oxygen at their stoichiometric ratio

$$
\mathrm{C}_{2} \mathrm{H}_{5}(\mathrm{OH})+3 \cdot \mathrm{O}_{2}=1 \cdot \mathrm{CO}_{2}+3 \cdot \mathrm{H}_{2} \mathrm{O} .
$$

From Equation (5) it follows that for the stoichiometric combustion of one mole of alcohol, three moles of oxygen are necessary. In other words, for an alcohol-alcohol pair, the molar stoichiometric coefficient is

$$
\chi_{0}^{\mathrm{O}}=3 .
$$

Taking into account the composition of the oxidizer in the form of air accepted in Equation (4), the molar stoichiometric coefficient of reaction will be

$$
\chi_{0}^{\mathrm{w}}=14.32
$$

Combustion reactions in power equipment are not necessarily in the stoichiometric ratio. This is taken into account by introducing an excess ratio of the oxidant and all reaction ratios are constructed using a molar ratio of components

$$
\chi^{\mathrm{w}}=\alpha \cdot \chi_{0}^{\mathrm{w}} .
$$

The excess factor of the oxidant indicates the excess of the molar ratio of the components ratio over the molar stoichiometric. Calculation of the composition of combustion products is based on the conditional fuel formula, including a fuel and an oxidizer taking into account the value of $\alpha$. So, for ethyl alcohol, taking into account Equations (1), (2), (4), (7) and (8) this formula will have the form

$$
\mathrm{C}_{2} \mathrm{H}_{6} \mathrm{O}\left(1+\alpha \cdot \chi_{0}^{\mathrm{w}} \cdot 0.419\right)^{\mathrm{N}}\left(\alpha \chi_{0}^{\mathrm{w}} \cdot 1.581\right) .
$$

In general, for arbitrary hydrocarbon oxygen-containing fuel burned in air, the conventional fuel formula will look like

$$
\mathrm{C}_{\mathrm{b}_{\mathrm{C}}} \mathrm{H}_{\mathrm{n}_{\mathrm{H}}} \mathrm{O}\left(\mathrm{b}^{\mathrm{O}}+\alpha \cdot \chi_{0}^{\mathrm{w}} \cdot 0.419\right)^{\mathrm{N}}\left(\alpha \cdot \chi_{0}^{\mathrm{w}} \cdot 1.581\right)
$$

The list of substances and ions that can be formed in the process of combustion of such fuel will be the following:

$$
\begin{aligned}
& {[\mathrm{CO}],\left[\mathrm{CO}_{2}\right],\left[\mathrm{H}_{2}\right],\left[\mathrm{O}_{2}\right],\left[\mathrm{H}_{2} \mathrm{O}\right],[\mathrm{OH}] .\left[\mathrm{N}_{2}\right]} \\
& {[\mathrm{NO}],[\mathrm{C}],[\mathrm{H}],[0],[\mathrm{N}] .}
\end{aligned}
$$

In order to determinate the composition of combustion products it is necessary to find 
the quantitative ratio of gases. The number of unknowns in the model is determined by the list of substances in Equation (11).

When varying the excess oxidizing factor, the amount and composition of the formed substances will change. For example, when $\alpha<1$, i.e. in the absence of an oxidant, there may be absent $\left[\mathrm{O}_{2}\right]$ in the mixture and $[\mathrm{CO}]$ and $\left[\mathrm{H}_{2}\right]$ may be present. In contrast, when $\alpha>1,\left[\mathrm{O}_{2}\right]$ and [NO] appear, but $[\mathrm{CO}]$ and $\left[\mathrm{H}_{2}\right]$ disappear. The composition of combustion products may include other substances of a more complex composition, but for any quantity their amount will be vanishing small. Therefore, they are not taken into account in calculations.

Thus, in Equation (11), a list of substances is encompassed covering practically important cases. For substances in the list described in Equation (11) the equations of chemical equilibrium are used. Their list is given in Table 1.

Table 1. The main reactions of the formation of dependent substances

\begin{tabular}{cc}
\hline 1 & $\mathrm{CO} \leftrightarrow \mathrm{C}+\mathrm{O}$ \\
\hline 2 & $\mathrm{CO}_{2} \leftrightarrow \mathrm{C}+2 \mathrm{O}$ \\
\hline 3 & $\mathrm{H}_{2} \mathrm{O} \leftrightarrow 2 \mathrm{H}+\mathrm{O}$ \\
\hline 4 & $\mathrm{OH} \leftrightarrow \mathrm{H}+\mathrm{O}$ \\
\hline 5 & $\mathrm{H}_{2} \leftrightarrow 2 \mathrm{H}$ \\
\hline 6 & $\mathrm{O}_{2} \leftrightarrow 2 \mathrm{O}$ \\
\hline 7 & $\mathrm{~N}_{2} \leftrightarrow 2 \mathrm{~N}$ \\
\hline 8 & $\mathrm{NO} \leftrightarrow \mathrm{N}+\mathrm{O}$ \\
\hline
\end{tabular}

For the equations given in the table, we can write the law of active masses, which is the ratio of the concentration of substances of the corresponding reactions, which is the constant of chemical equilibrium. For example, for the second equation from Table 1, the expression of the law will have the form

$$
\frac{\mathrm{c}(\mathrm{C}) \cdot \mathrm{c}^{2}(\mathrm{O})}{\mathrm{c}\left(\mathrm{CO}_{2}\right)}=\mathrm{K}_{\mathrm{CO}_{2}}(\mathrm{~T}) \text {. }
$$

Here, in Equation $(12) c(C), c(O)$ and $c\left(\mathrm{CO}_{2}\right)$ are the molar concentrations of carbon, oxygen and carbon dioxide, respectively, $\mathrm{K}_{\mathrm{CO}_{2}}(\mathrm{~T})$ is the constant of the chemical equilibrium for the formation of carbon dioxide at temperature $T$. The de-

gree of power is determined by the coefficient of the corresponding chemical element. The equations of the same form as Equation (12), written for the substances from Table 1, are part of the developing model.

It is more convenient to determine the composition of the gas mixture not through concentrations, but through their partial pressures. Equations of the form of Equation (12) can also be expressed through these quantities. The molar concentrations of combustion products are determined by, for example, one mole of fuel based on the expression of Equation (10).

In order to replace the concentrations with partial pressures, in addition to them, we introduce another variable $-M_{T}$, that is the number of moles of fuel considered. Its value will be determined during the calculations so that the quantities of the partial pressures of combustion products are numerically equal to their concentrations. Thus, the entire model includes 13 unknown values: 12 partial gas pressures form Equation (11) in the combustion products and the number of moles of the fuel $-M_{T}$.

The first eight equations, expressing the law of active masses for the reactions from Table 1 through the partial pressures of the combustion products will be as follows:

$$
\begin{aligned}
& \frac{\mathrm{P}_{\mathrm{C}} \cdot \mathrm{P}_{\mathrm{O}}}{\mathrm{P}_{\mathrm{CO}}}=\mathrm{K}_{\mathrm{CO}}(\mathrm{T}), \\
& \frac{\mathrm{P}_{\mathrm{C}} \cdot \mathrm{P}_{\mathrm{O}}^{2}}{\mathrm{P}_{\mathrm{CO}_{2}}}=\mathrm{K}_{\mathrm{CO}_{2}}(\mathrm{~T}), \\
& \frac{\mathrm{P}_{\mathrm{H}}^{2} \cdot \mathrm{P}_{\mathrm{O}}}{\mathrm{P}_{\mathrm{H}_{2} \mathrm{O}}}=\mathrm{K}_{\mathrm{H}_{2} \mathrm{O}}(\mathrm{T}), \\
& \frac{\mathrm{P}_{\mathrm{H}} \cdot \mathrm{P}_{\mathrm{O}}}{\mathrm{P}_{\mathrm{OH}}}=\mathrm{K}_{\mathrm{OH}}(\mathrm{T}), \\
& \frac{\mathrm{P}_{\mathrm{H}}^{2}}{\mathrm{P}_{\mathrm{H}_{2}}}=\mathrm{K}_{\mathrm{H}_{2}}(\mathrm{~T}), \\
& \frac{\mathrm{P}_{\mathrm{O}}^{2}}{\mathrm{P}_{\mathrm{O}_{2}}}=\mathrm{K}_{\mathrm{O}_{2}}(\mathrm{~T}),
\end{aligned}
$$




$$
\begin{aligned}
& \frac{\mathrm{P}_{\mathrm{N}}^{2}}{\mathrm{P}_{\mathrm{N}_{2}}}=\mathrm{K}_{\mathrm{N}_{2}}(\mathrm{~T}), \\
& \frac{\mathrm{P}_{\mathrm{N}} \cdot \mathrm{P}_{\mathrm{O}}}{\mathrm{P}_{\mathrm{NO}}}=\mathrm{K}_{\mathrm{NO}}(\mathrm{T}) .
\end{aligned}
$$

The chemical equilibrium constants are tabulated in the corresponding reference books and in calculations for the corresponding temperature they can be chosen or calculated with the help of approximation polynomials. In addition, they can be calculated on the basis of the enthalpies of formation and entropies of the substances included in the reactions under consideration, which, in turn, are also tabulated or can be calculated on the basis of approximation polynomials [10].

The following four equations will be written, expressing the law of matter conservation in a form of the equality of the number of atoms of the corresponding chemical element in fuel and combustion products. Let us use the fact that in the case under consideration, the partial pressures of gases in combustion products are numerically equal to their concentrations. The number of atoms in the fuel is taken on the basis of Equation (10), taking into account the number of considered molecules $M_{T}$ :

$$
\begin{aligned}
& \text { for }[C]: \mathrm{b}_{\mathrm{C}} \cdot \mathrm{M}_{\mathrm{T}}=\mathrm{P}_{\mathrm{CO}}+\mathrm{P}_{\mathrm{CO}_{2}}+\mathrm{P}_{\mathrm{C}^{\prime}} \\
& \text { for }[H]: \mathrm{b}_{\mathrm{H}} \cdot \mathrm{M}_{\mathrm{T}}=2 \cdot \mathrm{P}_{\mathrm{H}_{2} \mathrm{O}}+\mathrm{P}_{\mathrm{OH}}+2 \cdot \mathrm{P}_{\mathrm{H}_{2}}+\mathrm{P}_{\mathrm{H}},(22) \\
& \text { for }[O]:\left(\mathrm{b}_{\mathrm{O}}+\alpha \cdot \chi_{0}^{\mathrm{w}} \cdot 0.419\right) \cdot \mathrm{M}_{\mathrm{T}}=\mathrm{P}_{\mathrm{CO}}+\mathrm{P}_{\mathrm{H}_{2} \mathrm{O}}+ \\
& +2+\mathrm{P}_{\mathrm{OH}}+2 \cdot \mathrm{P}_{\mathrm{O}_{2}}+\mathrm{P}_{\mathrm{NO}}+\mathrm{P}_{\mathrm{O}^{\prime}} \\
& \text { for }[N]:\left(\alpha \cdot \chi_{0}^{\mathrm{w}} \cdot 1.581\right) \cdot \mathrm{M}_{\mathrm{T}}=2 \cdot \mathrm{P}_{\mathrm{N}_{2}}+\mathrm{P}_{\mathrm{NO}}+\mathrm{P}_{\mathrm{N}^{\prime}}(24)
\end{aligned}
$$

To lock the system, we write the Dalton law as the last equation, which expresses the equality of the sum of the partial pressures of combustion products to the pressure in the combustion chamber (furnace) $P_{\Sigma}$ :

$$
\begin{aligned}
& P_{\Sigma}=\mathrm{P}_{\mathrm{CO}}+\mathrm{P}_{\mathrm{CO}_{2}}+\mathrm{P}_{\mathrm{H}_{2} \mathrm{O}}+\mathrm{P}_{\mathrm{OH}}+\mathrm{P}_{\mathrm{H}_{2}}+\mathrm{P}_{\mathrm{O}_{2}} \mathrm{P}_{\mathrm{N}_{2}} \mathrm{P}_{\mathrm{NO}}+ \\
& +\mathrm{P}_{\mathrm{C}}+\mathrm{P}_{\mathrm{H}}+\mathrm{P}_{\mathrm{O}}+\mathrm{P}_{\mathrm{N}^{*}}
\end{aligned}
$$

\section{METHOD FOR MODEL PROBLEM SOLVING}

The recorded model is a system of nonlinear algebraic equations. To solve it, the Newton method can be used. It implies the linearization of the equations system and their solution with respect to corrections of unknown quantities. The peculiarity of the system obtained in the process of linearization is its poor conditionality. This is due to a very small magnitude of some members (partial pressures) and a large difference in the magnitudes between them. It may reach $10-15$ orders of magnitude. This leads to instability and a large error in the solution.

To increase the accuracy, the initial system of equations (13)-(25) was logarithmed. This leads to the fact that the members of the system, modified in such way, remain nonlinear, but will differ by no more than 10-15 times. But this approach does not completely solve the problem of a large difference between the terms of the linearized system equations. If the linearization is carried out in the usual way - with the use of the required quantities (partial pressures of the combustion products) as arguments, the corrections will be determined for them. Consequently, they can differ among themselves by the same $10-15$ orders of magnitude. To avoid this, we use the logarithms of the desired arguments (partial pressures and quantities $M_{T}$ ) as arguments for differentiation. For example, consider Equation (16). After the logarithm, we have

$$
\ln \left(\mathrm{P}_{\mathrm{C}}\right)+2 \cdot \ln \left(\mathrm{P}_{\mathrm{O}}\right)-\ln \left(\mathrm{P}_{\mathrm{CO}_{2}}\right)=\ln \left[\mathrm{K}_{\mathrm{CO}_{2}}(\mathrm{~T})\right]
$$

and after linearization

$$
\begin{aligned}
& 1 \cdot \Delta\left[\ln \left(\mathrm{P}_{\mathrm{C}}\right)\right]+2 \cdot \Delta\left[\ln \left(\mathrm{P}_{\mathrm{O}}\right)\right]-1 \cdot \Delta\left[\ln \left(\mathrm{P}_{\mathrm{CO}_{2}}\right)\right]= \\
& =(-1) \cdot\left\{\ln \left(\mathrm{P}_{\mathrm{C}}\right)+2 \cdot \ln \left(\mathrm{P}_{\mathrm{O}}\right)\right]-\ln \left(\mathrm{P}_{\mathrm{CO}_{2}}\right)- \\
& \left.-\ln \left(\mathrm{K}_{\mathrm{CO}_{2}}(\mathrm{~T})\right]\right\}^{0} .
\end{aligned}
$$

Here, the superscript 0 indicates that the expression in curly brackets is the initial approximation or is taken from the previous step of the calculation. To somewhat reduce the unwieldiness of the records, further in the text the expression of the form $\Delta\left[\ln \left(\mathrm{P}_{\mathrm{O}}\right)\right]$ will be represented as $\Delta_{\mathrm{O}}$, and, for example, $\Delta\left[\ln \left(\mathrm{P}_{\mathrm{CO}_{2}}\right)\right]$ as $\Delta_{\mathrm{CO}_{2}}$.

The processing of equations of the form as Equations (21)-(25) is thus reduced in difficulty. 
Consider, for example, Equation (21). After its logarithming there will be

$$
\ln \left(\mathrm{b}_{\mathrm{C}}\right)+\ln \left(\mathrm{M}_{\mathrm{T}}\right)=\ln \left(\mathrm{P}_{\mathrm{CO}}+\mathrm{P}_{\mathrm{CO}_{2}}+\mathrm{P}_{\mathrm{C}}\right),
$$

and after linearization

$$
\begin{aligned}
& \frac{\mathrm{P}_{\mathrm{CO}}}{\mathrm{A}} \cdot \Delta_{\mathrm{CO}}+\frac{\mathrm{P}_{\mathrm{CO}_{2}}}{\mathrm{~A}} \cdot \Delta_{\mathrm{CO}_{2}}+\frac{\mathrm{P}_{\mathrm{C}}}{\mathrm{A}} \cdot \Delta_{\mathrm{C}}-1 \cdot \Delta_{\mathrm{M}_{\mathrm{T}}}=, \\
& (-1) \cdot\left[\ln (\mathrm{A})-\ln \left(\mathrm{M}_{\mathrm{T}}\right)-\ln \left(\mathrm{b}_{\mathrm{C}}\right)\right]^{0}
\end{aligned}
$$

where $\mathrm{A}=\mathrm{P}_{\mathrm{CO}}+\mathrm{P}_{\mathrm{CO}_{2}}+\mathrm{P}_{\mathrm{C}}$.

By transforming the original system described by Equations (13)-(25) in the manner described above, we obtain a linearized system of equations:

$$
\begin{aligned}
& 1 \cdot \Delta_{\mathrm{C}}+1 \cdot \Delta_{\mathrm{O}}-1 \cdot \Delta_{\mathrm{CO}}=(-1) \cdot\left\{\ln \left(\mathrm{P}_{\mathrm{C}}\right)+\right. \\
& \left.\ln \left(\mathrm{P}_{\mathrm{CO}}\right)-\ln \left(\mathrm{P}_{\mathrm{C}}\right)-\ln \left[\mathrm{K}_{\mathrm{CO}}(\mathrm{T})\right]\right\}^{0}, \\
& 1 \cdot \Delta_{\mathrm{C}}+2 \cdot \Delta_{\mathrm{O}}-1 \cdot \Delta_{\mathrm{CO}_{2}}= \\
& (-1) \cdot\left\{\ln \left(\mathrm{P}_{\mathrm{C}}\right)+2 \cdot \ln \left(\mathrm{P}_{\mathrm{O}}\right)-\right. \\
& \left.\ln \left(\mathrm{P}_{\mathrm{H}_{2} \mathrm{O}}\right)-\ln \left[\mathrm{K}_{\mathrm{H}_{2} \mathrm{O}}(\mathrm{T})\right]\right\}^{0}, \\
& 2 \cdot \Delta_{\mathrm{H}}+1 \cdot \Delta_{\mathrm{O}}-1 \cdot \Delta_{\mathrm{H}_{2} \mathrm{O}}= \\
& (-1) \cdot\left\{2 \cdot \ln \left(\mathrm{P}_{\mathrm{H}}\right)+\ln \left(\mathrm{P}_{\mathrm{O}}\right)-\right. \\
& \left.\ln \left(\mathrm{P}_{\mathrm{H}_{2} \mathrm{O}}\right)-\ln \left[\mathrm{K}_{\mathrm{H}_{2} \mathrm{O}}(\mathrm{T})\right]\right\}^{0}, \\
& 1 \cdot \Delta_{\mathrm{H}}+1 \cdot \Delta_{\mathrm{O}}-1 \cdot \Delta_{\mathrm{OH}}= \\
& (-1) \cdot\left\{\ln \left(\mathrm{P}_{\mathrm{H}}\right)+\ln \left(\mathrm{P}_{\mathrm{O}}\right)-\right. \\
& \left.\ln \left(\mathrm{P}_{\mathrm{OH}}\right)-\ln \left[\mathrm{K}_{\mathrm{OH}}(\mathrm{T})\right]\right\}^{0}, \\
& 2 \cdot \Delta_{\mathrm{H}}-1 \cdot \Delta_{\mathrm{H}_{2}}=(-1) \cdot\left\{2 \cdot \ln \left(\mathrm{P}_{\mathrm{H}}\right)-\right. \\
& \left.\ln \left(\mathrm{P}_{\mathrm{H}_{2}}\right)-\ln \left[\mathrm{K}_{\mathrm{H}_{2} \mathrm{O}}(\mathrm{T})\right]\right\}^{0}, \\
& 2 \cdot \Delta_{\mathrm{O}}-1 \cdot \Delta_{\mathrm{O}_{2}}=(-1) \cdot\left\{2 \cdot \ln \left(\mathrm{P}_{\mathrm{O}}\right)-\right. \\
& \left.\ln \left(\mathrm{P}_{\mathrm{O}_{2}}\right)-\ln \left[\mathrm{K}_{\mathrm{O}_{2}}(\mathrm{~T})\right]\right\}^{0}, \\
& 2 \cdot \Delta_{\mathrm{N}}-1 \cdot \Delta_{\mathrm{N}_{2}}=(-1) \cdot\left\{2 \cdot \ln \left(\mathrm{P}_{\mathrm{N}}\right)-\right. \\
& \left.\ln \left(\mathrm{P}_{\mathrm{N}_{2}}\right)-\ln \left[\mathrm{K}_{\mathrm{N}_{2}}(\mathrm{~T})\right]\right\}^{0}, \\
& 1 \cdot \Delta_{\mathrm{N}}+1 \cdot \Delta_{\mathrm{O}}=(-1) \cdot\left\{\ln \left(\mathrm{P}_{\mathrm{N}}\right)+\right. \\
& (3) \\
& (3)
\end{aligned}
$$

$$
\left.\ln \left(\mathrm{P}_{\mathrm{O}}\right)+\ln \left(\mathrm{P}_{\mathrm{NO}}\right)-\ln \left[\mathrm{K}_{\mathrm{H}_{2}}(\mathrm{~T})\right]\right\}^{0}
$$

for $[\mathrm{C}]$

$$
\begin{aligned}
& \frac{\mathrm{P}_{\mathrm{CO}}}{\mathrm{A}} \cdot \Delta_{\mathrm{CO}}+\frac{\mathrm{P}_{\mathrm{CO}_{2}}}{\mathrm{~A}} \cdot \Delta_{\mathrm{CO}_{2}}+\frac{\mathrm{P}_{\mathrm{C}}}{\mathrm{A}} \cdot \Delta_{\mathrm{C}}-1 \cdot \Delta_{\mathrm{M}_{\mathrm{T}}}= \\
& =(-1) \cdot\left[\ln (\mathrm{A})-\ln \left(\mathrm{M}_{\mathrm{T}}\right)-\ln \left(\mathrm{b}_{\mathrm{C}}\right)\right]^{0},
\end{aligned}
$$

for $[\mathrm{H}]$

$$
\begin{aligned}
& \frac{2 \cdot \mathrm{P}_{\mathrm{H}_{2} \mathrm{O}}}{\mathrm{V}} \cdot \Delta_{\mathrm{H}_{2} \mathrm{O}}+\frac{\mathrm{P}_{\mathrm{OH}}}{\mathrm{V}} \cdot \Delta_{\mathrm{OH}}+\frac{2 \cdot \mathrm{P}_{\mathrm{H}_{2} \mathrm{O}}}{\mathrm{V}} \cdot \Delta_{\mathrm{H}_{2} \mathrm{O}}+ \\
& \frac{\mathrm{P}_{\mathrm{H}}}{\mathrm{V}} \cdot \Delta_{\mathrm{H}}-1 \cdot \Delta_{\mathrm{M}_{\mathrm{T}}}=(-1) \cdot\left[\ln (\mathrm{V})-\ln \left(\mathrm{M}_{\mathrm{T}}\right)-\ln \left(\mathrm{b}_{\mathrm{H}}\right]^{0},\right.
\end{aligned}
$$

where $\mathrm{V}=2 \cdot \mathrm{P}_{\mathrm{H}_{2} \mathrm{O}}+\mathrm{P}_{\mathrm{OH}}+\mathrm{P}_{\mathrm{H}}$;

for $[\mathrm{O}]$

$$
\begin{aligned}
& \frac{\mathrm{P}_{\mathrm{CO}}}{\mathrm{B}} \cdot \Delta_{\mathrm{CO}}+\frac{2 \cdot \mathrm{P}_{\mathrm{CO}_{2}}}{\mathrm{~B}} \cdot \Delta_{\mathrm{CO}_{2}}+\frac{\mathrm{P}_{\mathrm{H}_{2} \mathrm{O}}}{\mathrm{B}} \cdot \Delta_{\mathrm{H}_{2} \mathrm{O}}+ \\
& \frac{\mathrm{P}_{\mathrm{OH}}}{\mathrm{B}} \cdot \Delta_{\mathrm{OH}}+\frac{2 \cdot \mathrm{P}_{\mathrm{O}_{2}}}{\mathrm{~B}} \cdot \Delta_{\mathrm{O}_{2}}+ \\
& +\frac{\mathrm{P}_{\mathrm{NO}}}{\mathrm{B}} \cdot \Delta_{\mathrm{NO}}+\frac{\mathrm{P}_{\mathrm{O}}}{\mathrm{B}} \cdot \Delta_{\mathrm{O}}-1 \cdot \Delta_{\mathrm{M}_{\mathrm{T}}}= \\
& =(-1) \cdot\left[\ln (\mathrm{B})-\ln \left(\mathrm{M}_{\mathrm{T}}\right)-\ln \left(\mathrm{b}_{\mathrm{O}}+\alpha \cdot \chi_{0}^{\mathrm{w}} \cdot 0.419\right)\right]^{0},
\end{aligned}
$$

where $\mathrm{B}=\mathrm{P}_{\mathrm{CO}}+2 \cdot \mathrm{P}_{\mathrm{CO}_{2}}+\mathrm{P}_{\mathrm{H}_{2} \mathrm{O}}+\mathrm{P}_{\mathrm{OH}}+2 \cdot \mathrm{P}_{\mathrm{O}_{2}}+\mathrm{P}_{\mathrm{NO}}+\mathrm{P}_{\mathrm{O}}$; for $[\mathrm{N}]$

$$
\begin{aligned}
& \frac{\mathrm{P}_{\mathrm{N}_{2}}}{\mathrm{Z}} \Delta_{\mathrm{N}_{2}}+\frac{\mathrm{P}_{\mathrm{NO}}}{\mathrm{Z}} \cdot \Delta_{\mathrm{NO}}+\frac{\mathrm{P}_{\mathrm{N}}}{\mathrm{Z}} \cdot \Delta_{\mathrm{N}}-1 \cdot \Delta_{\mathrm{M}_{\mathrm{T}}}= \\
& (-1) \cdot\left[\ln (\mathrm{Z})-\ln \left(\mathrm{M}_{\mathrm{T}}\right)-\ln \left(\alpha \cdot \chi_{0}^{\mathrm{w}} \cdot 1.581\right)\right]^{0},
\end{aligned}
$$

where $\mathrm{Z}=2 \cdot \mathrm{P}_{\mathrm{N}_{2}}+\mathrm{P}_{\mathrm{NO}}+\mathrm{P}_{\mathrm{N}}$; for $\left[\mathrm{P}_{\Sigma}\right]$

$$
\begin{aligned}
& \frac{\mathrm{P}_{\mathrm{CO}}}{\mathrm{G}} \times \Delta_{\mathrm{CO}}+\frac{\mathrm{P}_{\mathrm{CO}_{2}}}{\mathrm{G}} \times \Delta_{\mathrm{CO}_{2}}+\frac{\mathrm{P}_{\mathrm{H}_{2} \mathrm{O}}}{\mathrm{G}} \times \Delta_{\mathrm{H}_{2} \mathrm{O}}+ \\
& \frac{\mathrm{P}_{\mathrm{OH}}}{\mathrm{G}} \times \Delta_{\mathrm{OH}}+\frac{\mathrm{P}_{\mathrm{H}_{2}}}{\mathrm{G}} \times \Delta_{\mathrm{H}_{2}}+\frac{\mathrm{P}_{\mathrm{O}_{2}}}{\mathrm{G}} \times \Delta_{\mathrm{O}_{2}}+ \\
& \frac{\mathrm{P}_{\mathrm{N}_{2}}}{\mathrm{G}} \times \Delta_{\mathrm{N}_{2}}+\frac{\mathrm{P}_{\mathrm{NO}}}{\mathrm{G}} \times \Delta_{\mathrm{NO}}+\frac{\mathrm{P}_{\mathrm{C}}}{\mathrm{G}} \times \Delta_{\mathrm{C}}+ \\
& \frac{\mathrm{P}_{\mathrm{O}}}{\mathrm{G}} \times \Delta_{\mathrm{O}}+\frac{\mathrm{P}_{\mathrm{N}}}{\mathrm{G}} \times \Delta_{\mathrm{N}}=(-1) \times\left[\ln (\mathrm{G})-\ln \left(\mathrm{P}_{\Sigma}\right)\right]^{0},
\end{aligned}
$$


where $\mathrm{G}=\mathrm{P}_{\mathrm{CO}}+\mathrm{P}_{\mathrm{CO}_{2}}+\mathrm{P}_{\mathrm{H}_{2} \mathrm{O}}+\mathrm{P}_{\mathrm{OH}}+\mathrm{P}_{\mathrm{H}_{2}}+$

$$
+\mathrm{P}_{\mathrm{O}_{2}} \mathrm{P}_{\mathrm{N}_{2}}+\mathrm{P}_{\mathrm{NO}}+\mathrm{P}_{\mathrm{C}}+\mathrm{P}_{\mathrm{H}}+\mathrm{P}_{\mathrm{O}} \mathrm{P}_{\mathrm{N}}
$$

The solution is based on the assumption of isoenthalpy of the process in the combustion chamber (furnace) of power equipment. For the selected pair, the fuel-oxidant with the enthalpies $I^{(F)}$ and $I^{(O)}$ known for them and the given value $\chi^{w}[4]$ of the molar ratio of the component ratio, the enthalpy of fuel is calculated:

$$
I^{(T)}=I^{(r)}+\chi^{w} \cdot I^{(0)}
$$

Further, the calculation process is constructed in accordance with the following algorithm:

1. Select a certain temperature $T^{0}$ (initial approximation). It is considered to be realizable at the considered moment in the combustion chamber: $T_{i}=T^{0}$.

2. Using the iterative process on the basis of the linearized model Equations (30)-(42), the composition (partial pressures $P_{i}$, and hence mole fractions) of the combustion products corresponding to the current temperature under consideration $T_{i}$ is determined. As noted earlier, the values of chemical equilibrium constants required for this calculation can be taken from tables or calculated using approximate polynomials similar to those given in [10].

3. The enthalpies $I_{i}$ of combustion products corresponding to the current temperature under consideration $T_{i}$ are determined. These quantities can also be taken from tables or calculated using approximate polynomials like those given in [10].

4. Using the values of partial pressures as values of the mole fraction of the corresponding gases included in the composition of combustion products, their enthalpy $I_{C P}$ is calculated:

$$
I_{C P}=\Sigma_{i}\left(P_{i} \cdot I_{i}\right) .
$$

5. The values of enthalpies of fuel and combustion products at the current temperature under consideration are compared. It should be taken into account that the calculated partial pressure values used in calculations are numerically equal to molar concentrations only when moles of fuel are considered. In other words, the comparison of enthalpies must take place in the form of the relation

$$
M_{T} \cdot I^{(T)} \Leftrightarrow I_{C P} .
$$

6. In the case of the equality of these values or the admissible value of deviation, the temperature and the composition of combustion products are considered to be certain. The calculation is stopped. Otherwise, proceed to the next step.

7. Depending on the excess of the left or right part of Equation (45), the value of the current temperature $T_{i}$ is adjusted to increase or decrease. With the new value we proceed to point 2 of the algorithm and repeat all calculations.

The basis of calculations is the assumption that the combustion process is isoenthalpic. Such a situation is observed only in separate power plants. For example, in the combustion chambers of the liquid-propellant rocket (LPR) due to a specially organized cooling system. This approach can be realized also in the calculation of processes in the cylinder of the internal combustion engine (ICE) within the limits of one step of its operation. This is due to the speed of flowing processes and, accordingly, a small fraction of losses through the walls of the cylinder. In the overwhelming majority of energy devices, the conditions of isoenthalpy of the combustion process are not feasible.

\section{DETERMINATION OF}

\section{THE TEMPERATURE AND COMPOSITION OF THE PRODUCTS OF COMBUSTION OF ETHYL ALCOHOL IN THE AIR}

Ethyl alcohol is chosen as a fuel for solving the model problem due to its widespread distribution and the availability of results suitable for checking the adequacy of the developed model. Thus, in [10], the results of calculating the combustion of ethyl alcohol in air with a change in the range 0.7-1.4 are given. Calculations covering a broader range of change $0.5-2$ were performed. The calculated temperatures and the partial pressures of some gases should be performed. A part of the substances for comparison will be chosen based on their significant share in the composition of combustion products. This is due to the fact that they mainly 
determine the enthalpy of the gas mixture and, consequently, its temperature. We also consider the quantities of partial pressures of carbon monoxide (carbon monoxide) and nitrogen oxides. This is due to the fact that they determine the harmful emissions of combustion products.

The justification of consideration that air contains only oxygen and nitrogen was performed above. In addition, the conditions for using alcohol with $100 \%$ concentration will be given in calculations. This is done to simplify the model and the calculations based on it. In practice, this does not correspond to reality, and alcohol always contains some amount of water in its composition. So, in [10] we give the results for the case of alcohol with $5 \%$ of $\mathrm{H}_{2} \mathrm{O}$. In addition, the content of air in the quantity of argon and carbon dioxide (in the range of 1\%) is taken into account. The deviation of the conditions laid down in the calculations from the reference data [10] will allow us to evaluate the sensitivity of the developed model to the error of the data input.

In Table 2, the calculation results are based on the model described by Equations (30)-(42) for various values of $\alpha$. In Table 3, the data taken

Table 2. Results of the calculation for determination of the composition and temperature of combustion products of ethyl alcohol in air based on the model (30-42) for different values of a

\begin{tabular}{c|c|c|c|c}
\hline $\boldsymbol{a}$ & $\mathbf{P}_{\mathrm{H}_{2}}$ & $\mathbf{P}_{\mathrm{O}_{2}}$ & $\mathbf{P}_{\mathrm{N}_{\mathbf{2}}}$ & $\mathbf{P}_{\mathrm{NO}}$ \\
\hline 0.5 & $1.46 \mathrm{E}-01$ & $1.08 \mathrm{E}-11$ & $5.31 \mathrm{E}-01$ & $9.45 \mathrm{E}-09$ \\
\hline 0.6 & $9.41 \mathrm{E}-02$ & $3.73 \mathrm{E}-09$ & $5.76 \mathrm{E}-01$ & $4.26 \mathrm{E}-07$ \\
\hline 0.7 & $5.61 \mathrm{E}-02$ & $2.45 \mathrm{E}-07$ & $6.13 \mathrm{E}-01$ & $6.11 \mathrm{E}-06$ \\
\hline 0.8 & $2.93 \mathrm{E}-02$ & $7.68 \mathrm{E}-06$ & $6.44 \mathrm{E}-01$ & $5.10 \mathrm{E}-05$ \\
\hline 0.9 & $1.17 \mathrm{E}-02$ & $2.08 \mathrm{E}-04$ & $6.70 \mathrm{E}-01$ & $3.51 \mathrm{E}-04$ \\
\hline 1.0 & $2.96 \mathrm{E}-03$ & $4.27 \mathrm{E}-03$ & $6.88 \mathrm{E}-01$ & $1.72 \mathrm{E}-03$ \\
\hline 1.1 & $8.48 \mathrm{E}-04$ & $1.64 \mathrm{E}-02$ & $6.98 \mathrm{E}-01$ & $2.83 \mathrm{E}-03$ \\
\hline 1.2 & $2.96 \mathrm{E}-04$ & $2.99 \mathrm{E}-02$ & $7.06 \mathrm{E}-01$ & $2.99 \mathrm{E}-03$ \\
\hline 1.3 & $1.15 \mathrm{E}-04$ & $4.22 \mathrm{E}-02$ & $7.12 \mathrm{E}-01$ & $2.76 \mathrm{E}-03$ \\
\hline 1.4 & $4.69 \mathrm{E}-05$ & $5.32 \mathrm{E}-02$ & $7.18 \mathrm{E}-01$ & $2.40 \mathrm{E}-03$ \\
\hline 1.5 & $1.98 \mathrm{E}-05$ & $6.30 \mathrm{E}-02$ & $7.23 \mathrm{E}-01$ & $2.02 \mathrm{E}-03$ \\
\hline 1.6 & $8.62 \mathrm{E}-06$ & $7.24 \mathrm{E}-02$ & $7.28 \mathrm{E}-01$ & $1.68 \mathrm{E}-03$ \\
\hline 1.7 & $3.79 \mathrm{E}-06$ & $8.09 \mathrm{E}-02$ & $7.34 \mathrm{E}-01$ & $1.38 \mathrm{E}-03$ \\
\hline 1.8 & $1.87 \mathrm{E}-06$ & $8.60 \mathrm{E}-02$ & $7.33 \mathrm{E}-01$ & $1.13 \mathrm{E}-03$ \\
\hline 1.9 & $8.88 \mathrm{E}-07$ & $9.20 \mathrm{E}-02$ & $7.36 \mathrm{E}-01$ & $9.22 \mathrm{E}-04$ \\
\hline
\end{tabular}

from [10] is matched with $r$. In Fig. 1, the results of calculating the combustion product parameters (solid lines) and the data taken from [10] (dashed lines) are given graphically. The dotted line represents the position corresponding to the stochiometric ratio of the components.

Also the partial pressure for $\mathrm{N}, \mathrm{O}, \mathrm{C}, \mathrm{H}$ and $\mathrm{OH}$ has been calculated, but due to its minor magnitude (power not greater than -3 ).

The comparison of graphs shows a qualitative coincidence of the results under consideration. Significant discrepancies are observed for the temperature (Fig. 1(a)) and the partial pressure of water vapour (Fig. 1(c)). The quantitative value of these discrepancies can be estimated from the data given in Table 4.

Deviation in the determination of the temperature and partial pressure of water vapour can be explained by the difference in the composition of the fuel taken in the calculations and data used from the reference book [10]. In the latter case, the content of 5\% water leads to decreasing enthalpy in comparison with $100 \%$ alcohol and, consequently, to decreasing in temperature of the products of combustion. Exactly, this is observed in Fig. 1. The data provided in Table 4 shows that the relative difference between the temperatures under consideration does not exceed $2.8 \%$. The error was determined with respect to the calculated temperature. This value allows us to estimate the parametric sensitivity of the developed model: $5 \%$ change in the composition of the fuel leads to $2.8 \%$ deviation of the calculated temperature value. A similar reason explains the deviation in the determination of the partial pressure of water vapour (Fig. 1(d)). It is precisely the presence of $5 \%$ of water in fuel that leads to an increase in the values of the data from the reference book [10] as compared with the calculated values. The relative error does not exceed $1.1 \%$. This is shown in Table 4. The pressure in the combustion chamber determines the error. In calculations, it was taken equal to 1 bar. All other errors of the considered quantities in Table 4 are less than those noted above.

Empty graphs in Table 4 are caused by lack of data in [10]. When recording relative error values $\varepsilon$, only one significant digit after a decimal point was displayed. More digits are not needed in 


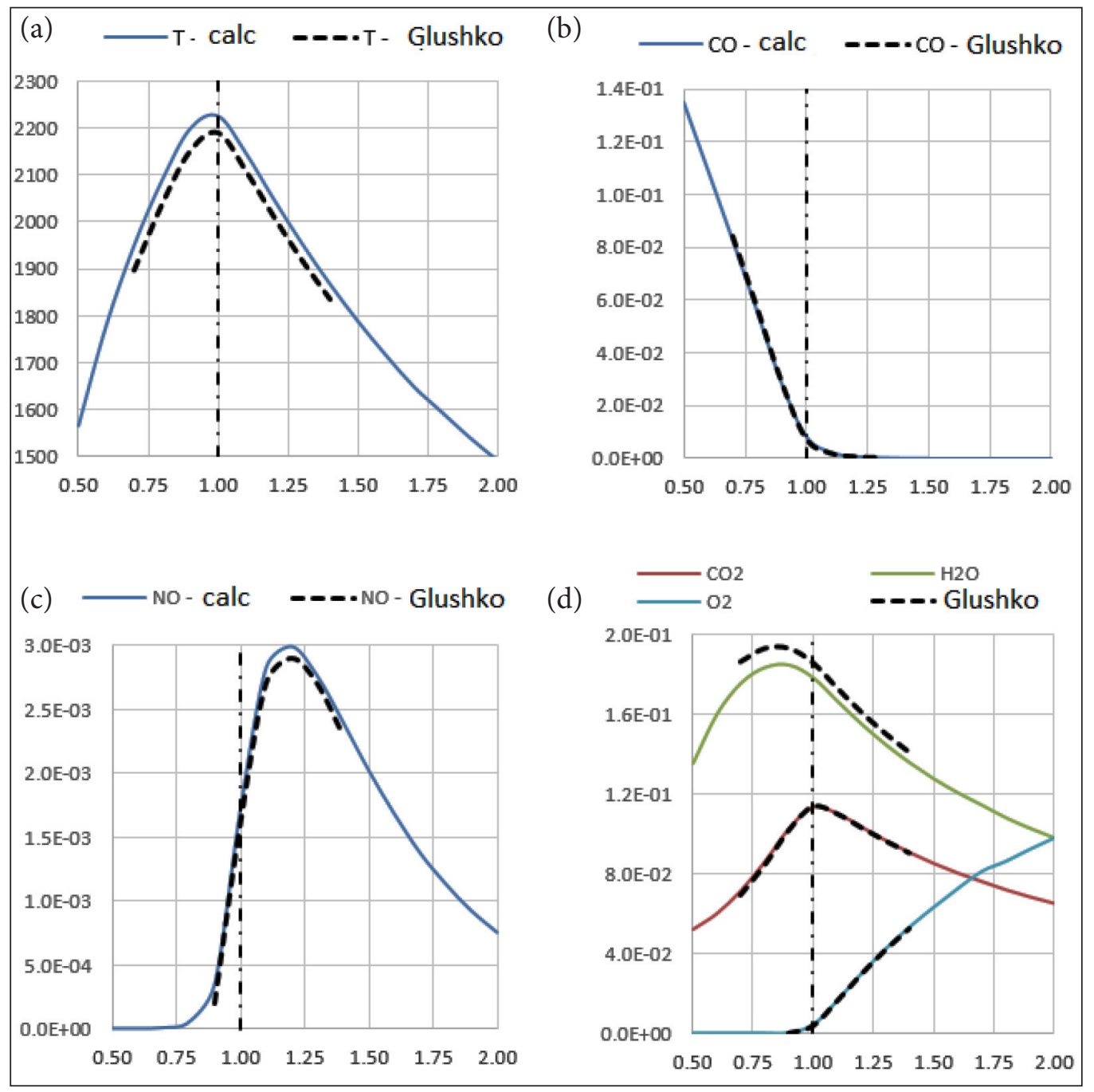

Fig. 1. Results of the calculations and data from the reference book [5] for the products of combustion of ethyl alcohol in air at different values: (a) temperature; (b) partial pressure of carbon monoxide; (c) partial pressure of nitrogen oxide; (d) partial pressures of carbon dioxide, water vapour and free oxygen

Table 3. Results of the calculation for determination of the composition of the combustion products of ethyl alcohol in air from [5]

\begin{tabular}{ccccccccccc}
\hline $\boldsymbol{A}$ & $\mathbf{0 . 7}$ & $\mathbf{0 . 8}$ & $\mathbf{0 . 9}$ & $\mathbf{1}$ & $\mathbf{1 . 1}$ & $\mathbf{1 . 2}$ & $\mathbf{1 . 3}$ & $\mathbf{1 . 4}$ \\
\hline $\mathrm{T}, \mathbf{K}$ & $\mathbf{1 8 9 7}$ & $\mathbf{2 0 3 8}$ & $\mathbf{2 1 5 1}$ & $\mathbf{2 1 9 0}$ & $\mathbf{2 1 0 8}$ & $\mathbf{2 0 1 0}$ & $\mathbf{1 9 1 8}$ & $\mathbf{1 8 3 5}$ \\
\hline $\mathrm{P}_{\mathrm{CO}}$ & $8.42 \mathrm{E}-02$ & $5.71 \mathrm{E}-02$ & $2.91 \mathrm{E}-02$ & $7.50 \mathrm{E}-03$ & $1.90 \mathrm{E}-03$ & $6.00 \mathrm{E}-04$ & $2.00 \mathrm{E}-04$ & \\
\hline $\mathrm{P}_{\mathrm{CO}_{2}}$ & $6.91 \mathrm{E}-02$ & $8.41 \mathrm{E}-02$ & $1.02 \mathrm{E}-01$ & $1.14 \mathrm{E}-01$ & $1.10 \mathrm{E}-01$ & $1.03 \mathrm{E}-01$ & $9.64 \mathrm{E}-02$ & $9.03 \mathrm{E}-02$ \\
\hline $\mathrm{P}_{\mathrm{H}_{2} \mathrm{O}}$ & $1.86 \mathrm{E}-01$ & $1.93 \mathrm{E}-01$ & $1.93 \mathrm{E}-01$ & $1.86 \mathrm{E}-01$ & $1.73 \mathrm{E}-01$ & $1.61 \mathrm{E}-01$ & $1.50 \mathrm{E}-01$ & $1.41 \mathrm{E}-01$ \\
\hline $\mathrm{P}_{\mathrm{OH}}$ & & $2.00 \mathrm{E}-04$ & $7.00 \mathrm{E}-04$ & $2.00 \mathrm{E}-03$ & $2.00 \mathrm{E}-03$ & $1.40 \mathrm{E}-03$ & $9.00 \mathrm{E}-04$ & $6.00 \mathrm{E}-04$ \\
\hline $\mathrm{P}_{\mathrm{H}_{2}}$ & $5.36 \mathrm{E}-02$ & $2.75 \mathrm{E}-02$ & $1.07 \mathrm{E}-02$ & $2.30 \mathrm{E}-03$ & $6.00 \mathrm{E}-04$ & $2.00 \mathrm{E}-04$ & & \\
\hline $\mathrm{P}_{\mathrm{O}_{2}}$ & & $1.00 \mathrm{E}-04$ & $3.60 \mathrm{E}-03$ & $1.61 \mathrm{E}-02$ & $2.96 \mathrm{E}-02$ & $4.19 \mathrm{E}-02$ & $5.28 \mathrm{E}-02$ \\
\hline $\mathrm{P}_{\mathrm{N}_{2}}$ & $5.99 \mathrm{E}-01$ & $6.30 \mathrm{E}-01$ & $6.56 \mathrm{E}-01$ & $6.75 \mathrm{E}-01$ & $6.85 \mathrm{E}-01$ & $6.93 \mathrm{E}-01$ & $6.99 \mathrm{E}-01$ & $7.05 \mathrm{E}-01$ \\
\hline $\mathrm{P}_{\mathrm{NO}}$ & & $2.00 \mathrm{E}-04$ & $1.60 \mathrm{E}-03$ & $2.70 \mathrm{E}-03$ & $2.90 \mathrm{E}-03$ & $2.70 \mathrm{E}-03$ & $2.30 \mathrm{E}-03$ \\
\hline $\mathrm{P}_{\mathrm{H}}$ & $1.00 \mathrm{E}-04$ & $2.00 \mathrm{E}-04$ & $3.00 \mathrm{E}-04$ & $2.00 \mathrm{E}-04$ & & & & \\
\hline $\mathrm{P}_{\mathrm{O}}$ & & & $1.00 \mathrm{E}-04$ & $1.00 \mathrm{E}-04$ & & & \\
\hline
\end{tabular}


Table 4. Relative deviations for the values of the process of combustion of ethyl alcohol in air between the results of calculations and data from [5]

\begin{tabular}{|c|c|c|c|c|c|c|c|c|c|}
\hline \multirow[t]{2}{*}{$A$} & \multicolumn{3}{|c|}{0.7} & \multicolumn{3}{|c|}{1.0} & \multicolumn{3}{|c|}{1.4} \\
\hline & Calc & Glushko & $\mathbf{E}$ & Calc & Glushko & $\mathbf{E}$ & Calc & Glushko & $\mathbf{E}$ \\
\hline $\mathrm{T}, \mathrm{K}$ & 1951 & 1897 & $2.8 \%$ & 2225 & 2190 & $1.6 \%$ & 1869 & 1835 & $1.8 \%$ \\
\hline $\mathrm{P}_{\mathrm{CO}}$ & 8.29E-02 & $8.42 \mathrm{E}-02$ & $0.1 \%$ & 8.38E-03 & $7.50 \mathrm{E}-03$ & $0.1 \%$ & & & \\
\hline $\mathrm{P}_{\mathrm{NO}}$ & & & & $1.72 \mathrm{E}-03$ & $1.60 \mathrm{E}-03$ & $0.0 \%$ & $2.40 \mathrm{E}-03$ & $2.30 \mathrm{E}-03$ & $0.0 \%$ \\
\hline $\mathrm{P}_{\mathrm{CO}_{2}}$ & 7.18E-02 & $6.91 \mathrm{E}-02$ & $0.3 \%$ & $1.13 \mathrm{E}-01$ & $1.14 \mathrm{E}-01$ & $0.0 \%$ & $9.06 \mathrm{E}-02$ & $9.03 \mathrm{E}-02$ & $0.0 \%$ \\
\hline $\mathrm{P}_{\mathrm{H}_{2} \mathrm{O}}$ & 1.76E-01 & $1.86 \mathrm{E}-01$ & $1.1 \%$ & $1.78 \mathrm{E}-01$ & $1.86 \mathrm{E}-01$ & $0.8 \%$ & 1.36E-01 & $1.41 \mathrm{E}-01$ & $0.5 \%$ \\
\hline $\mathrm{P}_{\mathrm{O}_{2}}$ & & & & $4.27 \mathrm{E}-03$ & $3.60 \mathrm{E}-03$ & $0.1 \%$ & $5.32 \mathrm{E}-02$ & $5.28 \mathrm{E}-02$ & $0.0 \%$ \\
\hline
\end{tabular}

engineering calculations. This approach, as well as minor errors, led to the appearance of zero values of errors in Table 4. All calculated and presented errors in Table 4 are less than 5\%, which corresponds to the permissible accuracy of engineering calculations. This makes it possible to use the data given in Table 1 as an expanded version of the basis for determining the composition and temperature of combustion products of ethyl alcohol in air at various $\alpha$ in comparison to [10].

\section{CONCLUSIONS}

For the determination of the quantitative composition of the conditional formula of gaseous fuel a mathematical model could be used, which includes Equations (30)-(42). In addition, the composition of combustion products and fuel enthalpy could be determined using as the initial data the quantities of measured technological parameters (for example, the cost of fuel components cost which corresponds to their temperatures in the combustion chamber) and known elemental (qualitative) fuel composition $([\mathrm{O}],[\mathrm{C}],[\mathrm{H}]$, etc.).

Mathematical accuracy of the model allows using the data obtained on its basis to evaluate the sensitivity of the calculation results to the inaccuracy of the measuring channel of the initial technological parameters.

When solving real technological problems, the enthalpy and entropy of combustion products should be determined with the maximum possible accuracy based on the tables or software complexes tabulating such a table. Polynomial dependencies for the determination of enthalp- ies and entropy of combustion products, due to significant approximation errors, cannot be used to solve an extended problem.

Received 27 January 2020 Accepted 20 March 2020

\section{References}

1. Jiabin Z., Wang T., Huang Y., Mao T., Zhong N. Size distribution of polycyclic aromatic hydrocarbons in urban and suburban sites of Beijing, China. Chemosphere. 2005. Vol. 61(6). P. 792-799.

2. Cai C., Geng F., Tie X., Qiongu Y., Junlin A. Characteristics and source apportionment of VOCs measured in Shanghai, China. Atmospheric Environment. 2010. Vol. 44(38). P. 5005-5014.

3. Barbella R., Ciajolo A., D’Anna A. The emission of heavy hydrocarbons from a diesel engine and a spray flame. Fuel. 1989. Vol. 68(6). P. 690-695.

4. Egolfopoulos F. N., Dimotakis P. E. Non-premixed hydrocarbon ignition at high strain rates. Proceedings of International Symposium on Combustion. The Combustion Institute. 1998. Vol. 27(1). P. 641-648.

5. Sangiovanni J. J., Liscinsky D. S. Soot formation characteristics of well-defined spray flames. Proceedings of International Symposium on Combustion. The Combustion Institute. 1984. Vol. 20(1). P. 1063-1073.

6. Alfèa M., Apicellaa J. B., Rouzaudb N., Tregrossia A., Ciajoloa A. The effect of temperature on soot properties in premixed methane flames. Combustion and Flame. 2010. Vol. 157(10). P. 641-648.

7. Bui-Pham M., Seshadri K., Williams F. A. The asymptotic structure of premixed methane-air 
flames with slow CO oxidation. Combustion and Flame. 1992. Vol. 89(3-4). P. 343-362.

8. Shigeyuki T., Ferran A., Keck J. C. A reduced chemical kinetic model for HCCI combustion of primary reference fuels in a rapid compression machine. Combustion and Flame. 2003. Vol. 133(4). P. 467-481.

9. Maksimov M. V., Brunetkin A. I., Bondarenko A. V. Model and method for determining the conditional formula of hydrocarbon fuel during combustion. Eastern-European Journal of Enterprise Technologies. 2013. Vol. 6(8(66)). P. 20-27.

10. Glushko V. P. (ed). Thermodynamic and Thermophysical Properties of Combustion Products: A Handbook. Moscow, Soviet Union: All-Union Institute of Scientific and Technical Information, 1972. $266 \mathrm{p}$.
Olexander Brunetkin, Yevhenii Dobrynin, Andrii Maksymenko, Oksana Maksymova, Svitlana Alyokhina

DEGUONIES TURINČIO ANGLIAVANDENILIŲ KURO SĄLYGINĖS FORMULĖS DEGIMO METU NUSTATYMO MODELIS IR METODAS

\section{Santrauka}

Straipsnyje analizuojamas nesertifikuoto kuro sudèties neapibrèžtumas ir kintamumas. Sukurtas matematinis modelis ir metodas, leidžiantis nustatyti tokio kuro sudètị degimo metu. Siūlomi optimalūs degimo proceso parametrai ir nustatomi taikomo metodo apribojimai, atsirandantys dèl modelio specifiškumo.

Raktažodžiai: deguonies turintis angliavandenilių kuras, kuro deginimas, degimo produktai, modeliavimo analizè, skaičiavimo metodas 